\title{
Hydrocarbons and fatty acids in two cores of Lake Huron sediments
}

\author{
Philip A. Meyers, Richard A. Bourbonniere* and Norishige Takeuchi \\ Department of Atmospheric and Oceanic Science, The University of Michigan, \\ Ann Arbor, MI 48109, U.S.A.
}

(Received 2 July 1979; accepted in revised form 15 April 1980)

\begin{abstract}
Compositions of aliphatic hydrocarbons and of fatty acids were analyzed in two half-meter cores of postglacial Lake Huron sediment. One core represents a continuous record of the past $450 \mathrm{yr}$ of sediment accumulation; the other consists of a surficial layer of modern sediment overlying $40 \mathrm{~cm}$ of $11,000-12,000$ yr-old sediment. Concentrations of hydrocarbons are higher in the younger core than in the older one. Based upon $n$-alkane distributions, this reflects a smaller input of terrigenous material to Lake Huron 11,000 yr ago rather than diagenetic losses. Most of the hydrocarhons present in the $450 \mathrm{yr}$-old core are allochthonous while half are autochthonous in the older core. Fatty acids are primarily of aquatic character in both cores, and their concentrations decrease rapidly with depth. Unsaturated acids disappear more quickly than do their saturated analogs. Fatty acid degradation occurs mostly in the biologically active zone of these sediments, and little further alteration of fatty acids appears to happen over times as long as $12,000 \mathrm{yr}$.
\end{abstract}

\section{INTRODUCTION}

MANY IMPORTANT sedimentary deposits have accumulated under freshwater environments. Knowledge of modern equivalents of organic matter sources and of early geolipid diagenesis is valuable in deciphering the geochemical histories of these deposits. In particular, carbon skeleton chain-length distributions of geolipids have often been utilized to provide such information.

From distributions of $n$-alkanes found in sediment cores from English lakes, Cranwell (1973a, 1977) identifies changes in the biota of the drainage basins serving these lakes. GASKELL et al. (1975) employ patterns of $n$-alkanes plus those of fatty acids to assess the relative contributions of marine versus terrigenous sources of organic matter in a core representing $10,000 \mathrm{yr}$ of sedimentary history from the northwest African continental shelf. These materials are particularly well preserved in this sediment sample, indicating low in situ microbial activity. In contrast, JoHNSON and CALDER (1973) found major changes in sediment lipids due to microbial activity in a tidal marsh environment. Hydrocarbon distribution patterns markedly changed with depth, although not as much as did those of fatty acids.

As a part of their study of sediment geolipids in a New England estuary, FarRINGTON and QUINN (1971a) found total fatty acid levels decreased with depth. The rate of decrease was greater for unsaturated than for saturated acids. In a study of Holocene sediment from a British Columbia fjord, Brown et al. (1972) also found that saturated and total fatty acid levels decreased with depth. Similar results were obtained from a number of estuarinc and coastal mar-

* Present Address: National Water Research Institute, Canada Centre for Inland Waters, Burlington, Ontario, Canada L7R 4A6. ine locations investigated by VAN VLEET and QUINN (1979). In these studies, it was concluded that these changes were postdepositional effects, because the ratio of fatty acids to total organic carbon also de creased. However, FARRINGTON et al. (1977) found the levels of total acids and of total organic carbon decreased together with depth at a constant ratio in a coastal marine sediment. Apparently, variations in types and amounts of fatty acids and also in diagenetic processes are found in different depositional environments.

From a survey of fatty acids in sediments from six English lakes, Cranwell (1974) concluded that the concentration of branched and cyclic saturated acids correlates directly with the productivity of lake surface waters and can be used as a paleolimnetic indicator. At the same time, chain-length distributions of $n$-alkanoic acids record the relative contributions of aquatic versus land sources of sediment organic matter. Also, fatty acid alteration and destruction are retarded in lakes having high sedimentation rates. However, such interpretations become complicated by diagenetic modifications of sedimented acids. Microbial activity may contribute significantly to fatty acids in sediments (Boon et al, 1975), and acids shorter than $\mathrm{C}_{20}$ may experience more degradation than longer-chain ones (MATSUDA and Koyama, 1977).

In an earlier study (MeYers and TAKFuCHI, 1979), we have shown that sediments from different parts of Lake Huron receive different lipid inputs. In this contribution we compare geolipid content of two cores of Lake Huron sediment which differ in age by $11,000 \mathrm{yr}$ but have similar locations.

\section{EXPERIMENTAL}

Two locations in southeastern Lake Huron provided the sediments analyzed in this study. The core designated 


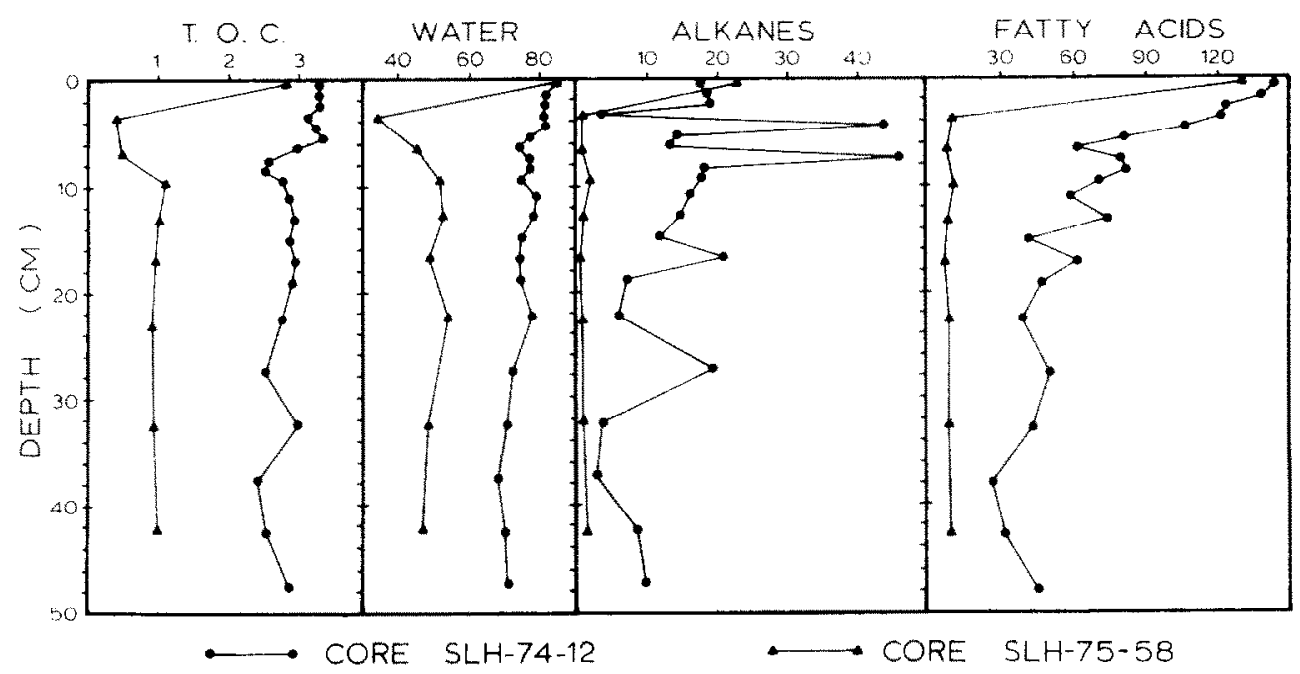

Fig. 1. Downcore comparisons of Lake Huron cores SLH-74-12 and SLH-75-58. Total organic carbon (T.O.C.) expressed in percent of dry sediment weight. Water content given in percent of wet sediment weight. Concentrations of total alkanes and total fatty acids are in $\mu \mathrm{g} / \mathrm{g}$ dry sediment.

SLH-74-12 was obtained from $91 \mathrm{~m}$ water depth. Modern sediments accumulate at this location at $1.1 \mathrm{~mm} / \mathrm{yr}$ according to ${ }^{210} \mathrm{~Pb}$ dating (J. A. RoBBiNs, in preparation). This core contained a uniform clay-silt texture throughout its $50 \mathrm{~cm}$ length. Core SLH-75-58 was from a location approximately $6.5 \mathrm{~km}$ to the east of core SLH-74-12 in $73 \mathrm{~m}$ of water. This core was not dated because a layer of sand was encountered at a depth of 3 to $5 \mathrm{~cm}$ and was an obvious discontinuity in the otherwise clay-silt texture of this $45 \mathrm{~cm}$ core. The presence of a sandy layer overlying a clay-silt or clay sediment containing some pebbles has been interpreted to indicate a diastem separating modern sediments from glaciolacustrine sediments (THomas et al., 1973). In the Laurentian Great Lakes, the period of glaciolacustrine deposition was $11,000-12,000$ yr before present. Hence, the sequence found in core SLH-75-58 represents a thin layer of recently deposited sediment overlying material $11,000-12,000 \mathrm{yr}$ old. These core locations are about $10 \mathrm{~km}$ north of station 55 of MEYERS and TAKEUCH (1979) and are further described in MFYERS et al (1979).

Analysis of the core sections was done as described by MEYers and TAKEUCHI (1979). Fatty acids and hydrocarbon contents were extracted using an alkaline hydrolysis scheme (FARRINGTON and QUINN, 1971b), isolated by chromatography, and analyzed by gas-liquid chromatography using both polar and non-polar liquid phases. Although individual compound identifications have not been verified by mass spectrometry, the tentative identifications in this report can be used to compare geolipid contents of the two cores.

\section{RESULTS AND DISCUSSION}

Downcore variations in the concentrations of total organic carbon, percent moisture, total fatty acids, and total aliphatic hydrocarbons of the two cores are compared in Fig. 1. In core SLH-74-12, a relatively high level of organic carbon is a reflection of the fine grain size of this sediment. The lack of major change with depth of organic carbon concentration combined with a slight but regular decrease in water content due to compaction agrees with visual observations that this is non-stratified sediment having no discon- tinuities. In contrast, core SLH-75-58 exhibits marked changes with depth. Concentrations of both organic carbon and water are highest at the surface and lowest at a depth of $3.5 \mathrm{~cm}$ in the sediment. This depth corresponds to the coarse-grained sandy layer.

Surface concentrations of total aliphatic hydrocarbons are similar at these two core locations. An overall, general decrease in concentration is found in core SLH-74-12, accompanied by considerable fluctuations and a concentration maximum at a depth of $7-8 \mathrm{~cm}$. In contrast, total aliphatic hydrocarbon concentrations in core SLH-75-58 decrease drastically from the surficial level to that found at a depth of $34 \mathrm{~cm}$. Little variation is found beneath this depth. The drastic decrease coincides with the sandy layer which is believed to represent an interruption of the sedimentary record. This layer also had the lowest level of total organic carbon found in core SLH-75-58, so the low level of aliphatic hydrocarbons may result from an overall low amount of organic matter in general. Such a paucity of organics could be a reflection of the relative coarseness of the sediment particles comprising this stratigraphic unit. However. it is interesting that the amounts of aliphatic hydrocarbons found below this layer remain low, even though the concentrations of total organic carbon climb to about three times that in the sandy layer.

Concentrations of total fatty acids in core SLH-74-12 drop from $138 \mu \mathrm{g} / \mathrm{g}$ dry sediment at the surface to $40 \mu \mathrm{g} / \mathrm{g}$ at $20 \mathrm{~cm}$ depth and then change little to $50 \mathrm{~cm}$. This is unlike total aliphatic hydrocarbon concentrations in this core which, except for two sections, change little with depth. In the surfical section of core SLH-75-58, fatty acids total $132 \mu \mathrm{g} / \mathrm{g}$. The concentration drops to $8 \mu \mathrm{g} / \mathrm{g}$ in the sandy layer at 3 to $5 \mathrm{~cm}$ depth and remains between 6 and $9 \mu \mathrm{g} / \mathrm{g}$ for the remainder of this core. This pattern resembles that of total aliphatic hydrocarbons. 


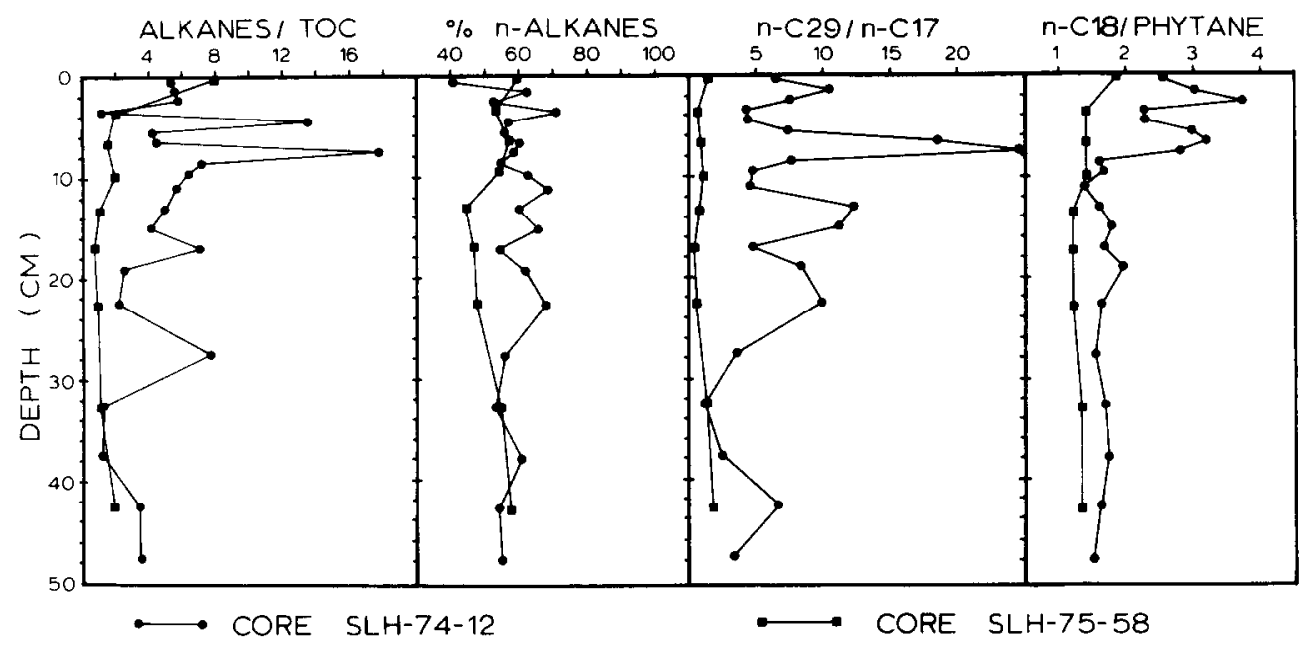

Fig. 2. Comparisons of aliphatic hydrocarbons in Lake Huron cores SLH-74-12 and SLH-75-58. Ratio of total alkanes to $\mathrm{TOC}$ is in $\mu \mathrm{g} / \mathrm{g}$ per $\%$ TOC. Other ratios are wt/wt ratios.

In general, the contribution of aliphatic hydrocarbons to the total organic matter is less below the sandy layer than within or above it and is also less than in core SLH-74-12. This is shown in the left panel of Fig. 2. The contributions of saturated hydrocarbons to total organic carbon are higher in most sections of core SLH-74-12 than in those of the older core, except near the surface and near the bottom of core SLH-74-12. The fractions of normal alkanes in the saturated hydrocarbons are represented in the second panel of this figure. For both cores, the values are around $60 \%$ and show no strong depth trends. In contrast, the ratios of $n-\mathrm{C}_{29}$ to $n-\mathrm{C}_{17}$ and of $n-\mathrm{C}_{18}$ to phytane are higher in core SLH-74-12 than in core SLH-75-58. This is especially evident in the top $8 \mathrm{~cm}$ of the younger core. As with other hydrocarbon data in the panels of this figure and in Fig. 1, core SLH-74-12 exhibits greater fluctuations than does core SLH-75-58.

Evidence of differences in sources of the organic materials is present in these two cores. Changes in hydrocarbon composition occur with depth and record variations in the makeup of the biological communities supplying organic materials to these sediments.

In the $7-8 \mathrm{~cm}$ section of core SLH-74-12, the $n-\mathrm{C}_{29} / n \mathrm{C}_{17}$ ratio approaches a value of 25 whereas the other sections of this core have an average value of 7. Because $n-C_{29}$ is abundant in land plants (Douglas and Eglinton, 1966; Cranwell, 1973a; Gigfr and SCHAFFNER, 1975) and $n-\mathrm{C}_{17}$ is prominent in algae (BLUMer et al., 1971; YoungBLOOD et al., 1971; Giger and SchaffNer, 1975; Paoletti et al., 1976), the ratio of these alkanes indicates the relative contributions of allochthonous and autochthonous hydrocarbons to sediment. This high value coincides with the highest concentration of alkanes both on an absolute basis (Fig. 1) and relative to TOC (Fig. 2) in core SLH-74-12. These peaks may record an increase in land runoff which was the result of conversion of the surrounding area from forest to farm land around 1840 .

A general increase in the $n-\mathrm{C}_{18} /$ phytane ratio occurs over the top $10 \mathrm{~cm}$ of core SLH-74-12. This can be due to changes in the source of hydrocarbons causing an increase in $n-C_{18}$ or a decrease in phytane or it may be the result of diagenetic loss of $n$-alkanes in the upper $9 \mathrm{~cm}$ of sediment. Straight-chain hydrocarbons are subject to quicker degradation in surface sediment than are isoprenoid compounds (BLUMER and SASS, 1972). In general, the amount of phytane shows neither an increasing nor a decreasing trend in this core. The concentration of $n-C_{18}$, however, averages one quarter less below $7-8 \mathrm{~cm}$ than above this depth. Hence, a decrease in $n-\mathrm{C}_{18}$ is responsible for the lower $n-C_{18} /$ phytane ratio below $7-8 \mathrm{~cm}$ seen in Fig. 2. The actual change in $n-\mathrm{C}_{18}$ concentration occurs as abruptly as the $n-C_{18} /$ phytane plot implies. In view of the $15 \%$ decrease in TOC concentrations which occurs between the 5-6 and 7-8 cm sections of this core, it is tempting to speculate that microbial processes cause a partial loss of $n$-alkanes and of organic matter in general in the biologically active surface zone of this core.

However, the depth at which $n-C_{18}$ decreases in this core is immediately below the high values of $n-\mathrm{C}_{29} / n-\mathrm{C}_{17}$ and total alkane/TOC ratios in Fig. 2. Furthermore, $n-\mathrm{C}_{27}$ is more abundant in all sections above $8 \mathrm{~cm}$ than is $n-C_{29}$ while the opposite is true below $8 \mathrm{~cm}$, and the concentration of total alkane hydrocarbons decreases over this depth range, although no important changes occur in percent $n$-alkanes. Consequently, it appears that the changes observed in aliphatic hydrocarbons reflect changing sources rather than diagenesis of hydrocarbons.

Near the bottom of core SLH-74-12, the major $n$-alkanes are $\mathrm{C}_{23}, \mathrm{C}_{25}, \mathrm{C}_{27}$ and $\mathrm{C}_{29}$. The approximate age of this sediment section is $400-450 \mathrm{yr}$ B.P. and its hydrocarbon distribution suggests important contributions of organic materials from forests. This 
section has a concentration of total alkanes which relative to TOC is similar to that found in most of core SLH-75-58. This deep section characterizes hydrocarbon input from a more natural era of the Great Lakes region than exists today.

$A s$ in core SLH-74-12, core SLH-75-58 surficial sediment contains $n-\mathrm{C}_{25}$ and $n-\mathrm{C}_{27}$ as major components and a large amount of $n \cdot C_{29}$, but a large amount of $n-C_{17}$ is also present. This n-alkane is the major component of total hydrocarbon contents of a freshwater blue-green alga (GIGER and SCHAFFNER, 1975) and of marine pelagic and benthic red algae (Blumer et al., 1971; Youngbloon et al., 1971). Consequently, the presence of this alkane indicates an abundance of phytoplankton in surface lake waters and incorporation of some of their constituents in the underlying sediments. However, the surficial sediments of core SLH-74-12 do not contain a large contribution of $n-\mathrm{C}_{17}$. Because both core locations are in the Goderich Basin and separated by only $6.5 \mathrm{~km}$ distance, this contrast is interesting.

There are a number of possible explanations for the different surficial sediment $n$-alkane distributions in these two cores. These include differences between types of organic matter incorporated in the sediments in 1974 and in 1975, changes in surface water productivity from 1974-75, and important contrasts between the benthic environments of these two areas. The first two possibilities are not likely to be important in this basin of Lake Huron because bioturbation and mixing of surface sediments will average any one year's sediment accumulation with the accumulation of the previous 3-10 yr (J. A. RoBbins, in preparation). This would diminish the effects of any annual variations in the record of sedimented materials.

There could, however, be differences in the henthic environments of these two locations. Although surficial sediment textures are similar, the site of core SLH-74-12 is deeper $(91 \mathrm{~m})$ than that of core SLH-75-58 $(73 \mathrm{~m})$. This depth difference, combined with the different subsurface sediment textures of the two locations could provide the basis for significant contrasts in benthic communities. For example, KREZOSKI (1976) found major differences in types and amounts of benthic invertebrates collected at locations in Lake Huron from depths of $65 \mathrm{~m}$ and $95 \mathrm{~m}$ and close to those sampled in this study. Therefore it is reasonable to expect similar differences in benthic algae and bacteria in locations from different depths. This in turn would be reflected in the hydrocarbon content of the sediments. As an example, $n-C_{17}$ is the major hydrocarbon of red benthic algae while it is a minor component of brown benthic algae (YouNGBLOOD et al., 1971). Also, some bacteria have been shown to contain large amounts of $n-\mathrm{C}_{17}$ while others do not (ALBRo, 1970). Therefore, the differences in hydrocarbon compositions between the surficial layers of these two cores is due to their fractions of hydrocarbons of a benthic origin relative to those obtained from plankton and land runoff. The contri- bution of shorter-chain $n$-alkanes is relatively large throughout core SLH-75-58, indicating the importance of algal or bacterial biomass as sources of organic matter in this core. This is further shown by the ratio of the $n-C_{29}$ and $n-C_{17}$ alkanes shown in Fig. 2. Low values indicate low amounts of higher plant hydrocarbons, represented by $n-C_{29}$, relative to the amounts of algal hydrocarbons, represented by $n-C_{1}$ ? The ratio is low throughout core SLH-75-58. Thus, it appears that less land-derived material is present in core SLH-75-58 than in the younger core. This lower abundance explains the overall lower alkane content of this core.

In the left panel of Fig. 3 concentrations of total fatty acids in these cores are compared to total organic carbon contents. The contribution of acids to TOC decreases rapidly with depth in these cores, and the rate of decrease is greater in core SLH-75-58. Only deep in core SLH-74-12 do the ratios of acids to TOC approach those in the older core.

While longer-chain $n$-alkanes characteristic of land plants are important in the aliphatic hydrocarbon compositions of these two cores, the fatty acid contents lack the longer-chain components which would be expected from terrigenous sources. The surficial sediment in core SLH-74-12 contains a fatty acid distribution dominated by palmitoleic acid followed by palmitic acid and is similar to distributions found in sediments from five of six locations by MEYERS and TAKEUCHI (1979) in transects across southern Lake Huron. Deeper in this core and throughout core SLH-75-58, palmitic acid dominates. These chainlength distributions are unlike those found in postglacial sediments by Cranwell (1974) and BroOKs et al. (1976) in several English lakes and by MEYers et al. (in press) in Pyramid lake, Nevada. These sediments and those deposited in two Eocene lakes (ARPINO, 1973) contain large contributions of $\mathrm{C}_{22}$ to $\mathrm{C}_{30}$ n-acids of land-derived origin.

Fatty acids undergo rapid alteration both in marine sediments (RHEAD et al., 1971; JOHNSON and CALDFR, 1973; FARRINGTON and QUINN, 1973; BOON et al.. 1975; Gaskell et al., 1975; FarRington et al., 1977: VAN VLEET and QUINN, 1979) and in lacustrine sediments (Matsuda and Koyama, 1977; Cranwell. 1978; Matsuda. 1978). The decrease in fatty acid concentrations relative to TOC in both Lake Huron cores shown in Fig. 3. strongly suggests the degradation of these lipids. This appears to occur in the top $10-12 \mathrm{~cm}$ of core SLH-74-12 and in the top $4 \mathrm{~cm}$ of core SLH-75-58. Further evidence of fatty acid alteration is given by the large decrease in percentage of unsaturated components in core SLH-74-12. In addition, the relative contribution of iso and anteiso acids, shown as percentage of branched acids in Fig. 3, increases with depth. These materials are abundant in sediment bacteria (LEO and PARKER, 1967; COOPER and Blumer, 1968; CranWELl. 1973b, 1974; JoHNS et al., 1977) and their presence indicates microbial biomass and alteration products in sediments (PARKER, 


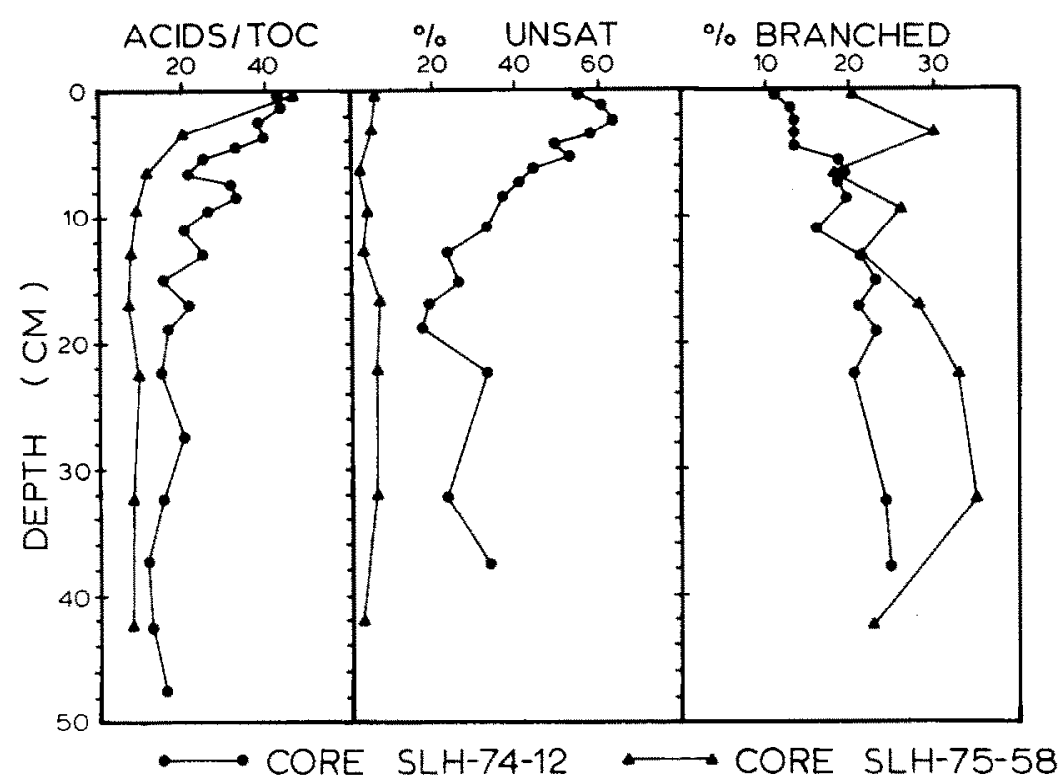

Fig. 3. Comparison of fatty acids in Lake Huron cores SLH-74-12 and SLH-75-58. Ratio of total acids to $\mathrm{TOC}$ is in $\mu \mathrm{g} / \mathrm{g}$ per \% TOC. Branched acids are iso and anteiso acids only.

1967; Boon et al., 1975; Brooks et al., 1977). An increase in branched acids accompanied by a decrease in unsaturated acids found to occur with depth in marsh sediments was interpreted by JoHNSON and CALDER (1973) to be the result of in situ microbial processes. Hence, the fatty acid contents of these Lake Huron sediments have experienced considerable microbial reworking.

As suggested by MATSUDA (1978), the acid composition of sediments may represent the residue of extensive microbial attack which occurs during the early stages of sedimentation. In support of this concept, chain-length distributions indicate a predominantly algal and microbial origin of fatty acids in Lake Huron surficial sediments whereas $n$-alkanes appear to be largely derived from terrigenous higher plant sources (MEYERS and TAKEUCHI, 1979). This has evidently been true for the periods of time represented by the two cores in this study and therefore implies that benthic processes provide an important contribution to the total fatty acid concentration of these sediments. This has also been indicated in marine (BOON et al., 1975; VAN VLEET and QUINN, 1979) and lacustrine sediments (MATSUDA and KoYAMA, 1977; MATSUDA, 1978).

However, evidence of both autochthonous and allochthonous sources of fatty acids has been preserved in the sediments of English lakes (CRANWELL, 1974; Brooks et al., 1976; Cranwell, 1978). Similar preservation is not evident in Lake Huron sediments nor in those of Lake Suwa (Matsuda and Koyama, 1977). A possible explanation for this difference is suggested by Huang and MeinsChein (1979) who postulate that the water circulation of Rostherne mere, one of the lakes studied by Brooks et al. (1976), is less effective than in Lake Suwa. This may result in more reducing bottom conditions in Rostherne mere which limits benthic microbial populations and consequently provides enhanced preservation of allochthonous organic matter in this English lake. In contrast, Lake Suwa experiences year-round wind-driven circulation which aerates bottom waters (NISHIMURA and Koyama, 1977) and allows an abundance of benthic flora and fauna. Similarly, Lake Huron waters circulate freely and replenish the bottom oxygen content (J. R. BENNETT, personal communication). Hence, alteration and degradation of organic constituents of the sediments of these two lakes can occur rapidly, and evidently fatty acids are more subject to attack than are $n$-alkanes.

Some important differences exist in the fatty acid contents of the two Lake Huron cores. Although the concentrations of acids in the surficial sections are very similar, the contribution of unsaturated acids is quite low throughout core SLH-75-58. This low level is not equalled in core SLH-74-12 even in the 450 yrold bottom sections. The rapid decreases in total acids and the percentage of unsaturated components evident in the upper portion of core SLH-74-12 cease at $12 \mathrm{~cm}$. Lack of further change in concentration or in chain-length distribution with greater depth in this core shows that little degradation of acids occurs beneath the biologically active zone of surface sediments. Those fatty acids which survive degradation may exist primarily in the bound state, as concluded by CRANWell (1978) and VAN VLeET and QunN (1979).

Although fatty acid and hydrocarbon compositions near the bottom of core SLH-74-12 become more similar to those of the glaciolacustrine portion of core SLH-75-58, they never achieve parity. Degradation of these types of organic compounds proceeds so slowly 
below the biologically active zone in Lake Huron sediments that $400 \mathrm{yr}$ is not sufficient time to equal the alterations that occur over an $11,000 \mathrm{yr}$ period. Furthermore, the slow degradation is inadequate to erase completely the character of geolipids introduced to sediments by settling processes and by postdepositional benthic production. As a consequence, the differences between the deeper sections of these two cores indeed record the original limnological environments which existed at the times these sediments accumulated.

Acknowledgements - We thank JOHN ROBBINS and CLAIRE SCHELSKE for helpful discussions concerning this manuscript and Lake Huron. The captains and crews of $R / V$ Roger $R$. Simons and of $R / V$ Laurentian assisted in collection of our sediment samples. We are grateful for financial support for parts of this study from the U.S. Environmental Protection Agency Large Lakes Laboratory and the Rackham School of The University Michigan. In addition, acknowledgement is made to the donors of the Petroleum Research Fund, administered by the Amcrican Chemical Society, for partial support of this work.

\section{REFERENCES}

ALBRo P. R. (1970) Bacterial hydrocarbons: occurrence. structure, and metabolism. Lipids 5, 320-325.

ARPINO P. (1973) Les lipides de sediments lacustres Eocenes. Ph.D. Thesis. Universite Louis Pasteur de Strasbourg.

Blumer M. and SASS J. (1973) Oil pollution: persistence and degradation of spilled fuel oil. Science 176, $1120-1122$

Blumer M., Guillard R. R. L. and Chase T. (1971) Hydrocarbons of marine phytoplankton. Mar. Biol. 8, 183-189.

Boon J. J., De Leeuw J. W. and Schenck P. A. (1975) Organic geochemistry of Walvis Bay diatomaceous ooze-I. Occurrence and significance of the fatty acids. Geochim. Cosmochim. Acta 39, 1559-1565.

Brooks P. W., Eglinton G., Gaskell S. J., McHugh D. J., Maxwell J. R. and Philp R. P. (1976) Lipids of recent sediments, part I: straight-chain hydrocarbons and carboxylic acids of some temperate lacustrine and subtropical lagoonal/tidal-flat sediment. Chem. Geol. 18, $21-38$.

Brooks P. W., Eglinton G., Gaskell S. J., McHugh D. J., Maxwell J. R. and PhilP R. P. (1977) Lipids of recent sediment, part II. Branched and cyclic alkanes and alkanoic acids of some temperate lacustrine and sub-topical lagoonal/tidal-flat sediments. Chem. Geol. 20, 180-204.

Brown F. S., Baedecker M. J., Nissfnatim A. and KapLAN I. R. (1972) Early diagenesis in a reducing fjord, Saanich Inlet. British Columbia-III. Changes in organic constituents of sediment. Geochim. Cosmochim. Acta 36, 1185-1203

COOPER W. J. and Blumer M. (1968) Linear, iso and anteiso fatty acids in recent sediments of the North Atlantic. Deep-Sea Res. 15, 535-540.

Cranwell P. A. (1973a) Chain-length distribution of $n$-alkanes from lake sediments in relation to post-glacial environmental change. Freshwater Biol. 3, 259-265.

Cranwell P. A. (1973b) Branched-chain and cyclopropanoid acids in a recent sediment. Chem. Geol. 11, 307-313.

Cranwell P. A. (1974) Monocarboxylic acids in lake sediments: Indicators, derived from terrestrial and aquatic biola, of paleoenvironmental trophic levels. Chem. Geol $14,1-14$.

Cranwell P. A. (1977) Organic geochemistry of Cam Loch (Sutherland) sediments. Chem. Geol. 20, 205.221.

Cranwell P. A. (1978) Extractable and bound lipid components in a freshwater sediment. Geochim. Cosmochim. Acta 42, 1523-1532.

Douglas A. G. and Eglinton G. (1966) The distribution of alkanes. In Comparative Phytochemistry (ed. T Swaine), pp. 187218 . Academic Press

Farrington J. W. and QuinN J. G. (1971a) Fatty acid diagenesis in Recent sediment from Narragansett Bay, $R$. I. Nature 230, 67-69.

FARRINGTON J. W. and QUINN J. G. (1971b) Comparison of sampling and extraction techniques for fatty acids in Recent sediments. Geochim. Cosmochim. Ac'ta 35 $735-741$.

FarRington J. W. and QuinN J. G. (1973) Biogeochemistry of fatty acids in Recent sediments from Narragansett Bay, R. I. Geochim. Cosmochim. Acta 37, 259-268.

Farrington J. W. Henrichs S. M. and Anderson R. (1977) Fatty acids and ${ }^{210} \mathrm{~Pb}$ geochronology of a sediment core from Buzzards Bay, Massachusetts. Geochim Cosmochim. Acta 41, 289 296.

Gaskell S. J., Morris R. J. Eglinton G. and Calvert S. E. (1975) The geochemistry of a Recent marine sediment off northwest Africa. An assessment of source of input and early diagenesis. Deep-Sea Res. 22, 777.789.

GIGER W. and SCHAFFNER C. (1975) Aliphatic, olefinic, and aromatic hydrocarbons in Recent sediments of a highly eutrophic lake. Advances in Organic Geochimistry 1975 pp. 375-390. Pergamon

Huang W.-Y. and Meinschein W. G. (1979) Sterols as ecological indicators. Geochim. Cosmochim. Acta 43. 739-745.

JohnS R. B., Perry G. J. and JACKSON K. S. (1977) Contribution of bacterial lipids to Recent marine sediments. Estuarine Coastal Mar. S(i. 5, 521. 529.

JoHNSON R. W. and CALder J. A. (1973) Early diagenesis of fatty acids and hydrocarbons in a salt marsh environment. Geochim. Cosmochim. Acta 37, 1943 1955.

KREZOSKI J. R. (1973) Macrobenthos and mixing processes in Lake Huron sediments. M.S. Thesis. The University of Michigan

LeO R. F. and Parker P. L. (1966) Branched-chain fatty acids in sediments. Science 152, 649-650.

Matsuda H. (1978) Early diagenesis of fatty acids in lacustrine sediments-- III. Changes in fatty acid composition in the sediments from a brackish lake. Geochim. Cosmochim. Acta 42, 10271034

Matsuda H. and Koroma T. (1977) Early diagenesis of fatty acids in lacustrine sediments. I. Identification and distribution of fatty acids in Recent sediment from a freshwater lake. Geochim. Cosmochim. Acta 41, 777. 783.

Meyers P. A. and Takeuchi N. (1979) Fatty acids and hydrocarbons in surficial sediments of Lake Huron. Org. Geochem. 1, 127 139.

Meyers P. A. Bourbonnilire R. A. and Takeuch N (1979) Southern I.ake Huron: Hydrocarbons and fatty acids in sediments. Spec. Rep. No. 72. Great Lakes Res. Div., Univ of Michigan. $65 \mathrm{pp}$.

Meyers P. A.. Maring H. B. and Bolrbonniere R. A. (in press) Alkane and alkanoic acid variations with depth in modern sediments of Pyramid Lake. In Adrunces in Organic Geochemistry 1979 (ed. A. G. Douglas and J. R Maxwell). Pergamon.

Nishimura M. and Koyama T. (1977) The occurrence of stanols in various living organisms and the behavior of sterols in contemporary sediments. Geochim. Cosmochim. Acta 41, 379385.

Paolettl C.. Pushparaj B., Florentano G., Capllila P. and Lt:ktKkr G. (1976) Unsaponifiable matter of green and blue-green algal lipids as a factor of biochemical 
differentiation of their biomass: 1. Total unsaponifiable and hydrocarbon fraction. Lipids 11, 258-265.

PARKer P. L. (1967) Fatty acids in Recent sediment. Contr. Mar. Sci, 12, 135-142.

Rhead M. M., Eglinton G., Draffan G. H. and EngLuND P. J. (1971) Conversion of oleic acid to saturated latty acids in Severn Estuary sediments. Nature 232, 327-330.

Thomas R. L., Kemp A. L. W. and Lewis C. F. M. (1973)
The surficial sediments of Lake Huron. Can. J. Earth Sci. 10, 226-271.

VAN VLeET E. S. and QuinN J. G. (1979) Early diagenesis of fatty acids and isoprenoid alcohols in estuarine and coastal sediments. Geochim. Cosmochim. Acta 43, 289-303.

Youngblood W. W., Blumer M., Guillakd R. K. and FIORE F. (1971) Saturated and unsaturated hydrocarbons in marine benthic algae. Mar. Biol. 8, 190-201. 